Neža Čebron Lipovec

\title{
Homage to a New Town in an Old One: Dequel's Bust of Pier Paolo Vergerio il Giovane
}

Keywords: collective memory, contested spaces, symbolic marking, public sculpture, Koper/Capodistria, Oreste Dequel

DOI: $10.4312 /$ ars.13.1.248-263

\section{Collective memory and symbolic marking of space}

"One can say that the city is the collective memory of its people, and like memory it is associated with objects and places. The city is the locus of collective memory" (Rossi, 1982, 130). In his statement, the postmodernist architect and theoretician, Aldo Rossi, concisely integrated the theory on collective memory, as developed by Maurice Halbwachs (2001), into his analysis of urban history, planning and design. However, urban planning in particular can work as an Althusserian ideological apparatus of the state (Rotar, 1980). Considering that urban environment is the space of representations (Lefebvre, 2013) par excellence, the attitude towards the urban, especially historical built environment as well as to public sculpture, consequently becomes a direct expression of power. In fact, the latter aims at representing the official memory of the groups in power, and hindering other collective memories that do not fit in dominant discourse (Halbwachs, 2001). Memorials especially, as intentional monuments, are representations of political power par excellence. In relation to the dominant power in society, art can be used in different modes (Šuvaković, 2015, 18): as performance of power through spectacularity; representation through mimesis; apology through allegorization, mythologization, fetishization, identification, didactics and optimal projection; subversion through criticism, action, engagement, activism, destruction; or as hiding power by exercising complete autonomy of art. A challenging context for investigating the importance of collective memory linked to space and art are contested spaces, especially in multi-ethnic areas.

In the present contribution we look at how the issue of different collective memories in a contested space is reflected in the attitude of creating new public sculpture. The case study is the multinational territory of the Slovene Coast, namely 
the city of Koper/Capodistria ${ }^{1}$ during the post-World War II period. A representative public sculpture was observed using formal analysis and the biographical method: the bust of Bishop Pier Paolo Vergerio il Giovane in Koper, made by the local artist Oreste Dequel in 1951.

\section{Collective memories in a contested space: Post-war northern Istria and its architecture}

Collective memory, as the social framework for remembering that also enables individual memories (Halbwachs, 2001), can directly affect the assessment of values in the built environment, especially in a historical sense. According to Halbwachs (2001, 143-146), the built environment carries our material signs and the signs of others. Hence, it is a container of collective memories since these can most easily be recalled within or through a solid, material reminder in which past events and relationships were lived. As Veschambre (2008) suggests, these material reminders survive generally as traces that in their original context were signs or marks, which, however, can lose meaning over time. However, in the process of heritagization (Harvey, 2001) these traces can be reinvested with new symbolism and "heritagized", and so serve as material support for claiming identity and memory by certain groups (Veschambre, 2008, 21). However, the inverse process also exists, and this is demolition. Following Halbwachs $(2001,145)$, when a group leaves its environment the collective memory can survive as long as the members of the group are alive, and then disappears when they vanish. If then, the built environment also disappears - through neglect or destruction/demolition - the possibility to recall those memories, with the help of material reminders, vanishes.

The issue is particularly challenging in contested multi-ethnic spaces, where the position of power switched. Considering that contested spaces are "[g]eographic locations where conflicts in the form of opposition, confrontation, subversion, and/ or resistance engage actors whose social positions are defined by differential control of resources and access to power" (Low, Lawrence-Zuñiga, 2003, 18), symbolic marking becomes a major tool of institutionalizing new powers. So, while heritagization has a constitutive, although selective role given its representation of the values of one social group, conversely demolition can be read as the symbolic negation of the other (Veschambre, 2008, 94). In order to shape a new official (national) memory the new ruling group constructs new narratives: this is based on socially organized forgetting, in which demolition aims at deleting the traces and the memory of the "unfitting" demographic, as well as on socially organized remembering, based on deliberate

1 Due to the limited space in the article, we use only the Slovenian name of the city. 
invention, emphasis and popularization of elements of consciousness (Wingfield, 2000, 246). As a result, the (non-)preservation of the historic environment, the new constructions as well public sculpture play a major role in establishing and promoting the new official memory.

An eloquent case of contested space where groups switched positions of power and established a new collective memory through interventions in the built environment is found in the northern part of the Istrian region (Slovenia). Istria is an historical regional crossroads, where several ethnicities mixed over the centuries, namely of Roman and Slavic origin (Italians, Slovenes, Croats), while Istria itself underwent significant political changes in the $20^{\text {th }}$ century. After 500 years of Venetian rule within the Serenissima (1279-1797), the $19^{\text {th }}$ century was mainly marked by the rule of the Austrian Empire, which promoted multiculturality and supported groups that had not been in positions of power - namely, Slavs. After World War I, the region was annexed by the Italian Kingdom, where one of the principal aims of the Fascist system was to annihilate the Slavic population in Istria - an approach that later escalated under Nazism. After World War II, Istria entered a crucial decade of status quo. In fact, due to the ethnic mix of the Istrian population - with a strong Italian presence along the urbanized coastline, and Slovenes and Croats in the rural hinterland the establishment of the border between liberal market-oriented Italy and socialist Yugoslavia demanded a long negotiation process. Consequently, in 1947, a small buffer-state along the southern border was formed, named the Free Territory of Trieste (FTT). The temporary state, divided into two zones, ${ }^{2}$ was officially multinational, supposedly promoting mutual respect among ethnic groups. In the Yugoslav part of the FTT, Zone B, the multinational aspect was strongly advocated in particular by the Slovene-Italian Antifascist Union (SIAU-UAIS), which promoted the concept of fratellanza, or brotherhood between the two nations (Troha, 2005; Rogoznica, 2011).

In the spirit of brotherhood that emerged from the common battle against Fascism and struggle for social revolution, a symbolic spatial intervention also took place in the historic core of Koper. As a sign of overcoming the past repressive system the large prison structure ${ }^{3}$ was demolished in 1948. Soon after, on its site a new ItalianSlovenian elementary school was built by 1951 (Čebron Lipovec, 2012, 214; Čebron

2 The FTT was formed after the Paris conference in 1947 and ceased after the signing of the London agreement in 1954. The territory was split into two zones: the western zone A with the larger Trieste/ Trst area was governed by the Allies' Military Administration; the eastern zone B stretched from the hills of Ankaran to the river Mirna in Istria, encompassing the Istrian coastal cities in between, it was governed by the Yugoslav Military Administration - Vojaška uprava jugoslovanske vojske VUJA. FTT had its own Statute that promoted mutual respect of all ethnic groups and was supposed to have a joint governor that was. (Bonin, 2005)

3 The site of the prisons was originally a Dominican monastery from the $13^{\text {th }}$ century, adapted into prisons in the early $19^{\text {th }}$ century with the advent of the Austrian rule. (Mileusnić, 2015) 
Lipovec, 2018, 219-221). While the demolition marked the intentional removal of reference to the negative past, the new building was a symbol of the positive future, and particularly of the fratellanza ideal (La nostra lotta (a), 1951). The project was signed by a local, unknown Slovene architect from nearby Trieste, Ervinio Velušček. The school ${ }^{4}$ was never entirely realized since only one of the three planned wings was built, and this hosted only the Slovenian school.

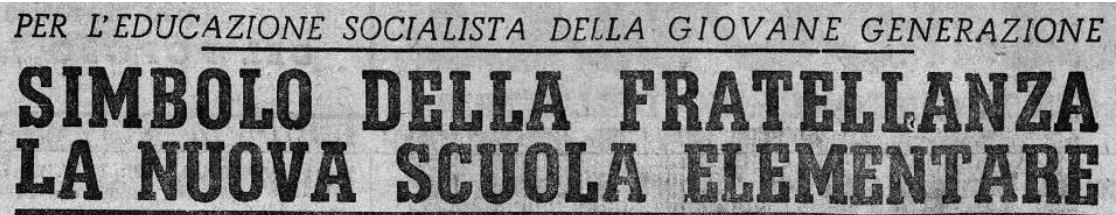

Sedici aule moderne e piene di luce ospiteranno gli alumi italiani e sloveni. - Dove sorgeva la triste galera di Capodistria si innalza l'edificio dove si forgerasto i fu uri cittadini Tra una moltitidine di scciari, insegnanti e rarinresentanti del Pofece Po: olase, si e inaugurato sabato 3 marzo 11 primo padiglione de'la nuova Seroia Itaio-slava. Questo stabile, frcico in t tta la sua bellezza moderna e confortevole, si erge, no dato di live e di aria, su quello stesso posto dove, fino a pochi a ini fa s ergeva, buio e triste pur nel suo cru-

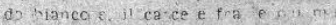
ra tanto imnocenti vittime del fascismo sono stzie martoriate, nelle cui crile tonti cervelli anelonti aila il hertá hamno lavo ato neil'attesa $d$ i trima i radiciso. Quel domani, che purticappo molti di essi non hanno po-

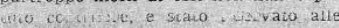
giovani vite che d'o 2 in not of iranno al passante lo schiamazzar pio iogo deile in a v van;

di quei mondono e triste rumore di sba e controlizie dal guardiano; a quelle giovani vite che sabato si sono accalcate festosamente nell ampio cc idoio in atiesa dell'inaugurazione. Ha pariato re iprimo il com . Fitan Carlo, n eniclinte del C.P. Distrettuale seguito dana seig cheria del C.R. Cittadito, cemo. Crollini Elia. Ambidue hanno nico: dato il triste passato, quando agli slovenul era negata la onssibilta di avere una propria scuola e hanmo fatto un confronto con il presente che vede italiani e sloveni $\mathrm{fl}$ nalmente affraiellati, con pari diritti e uniti nella com ne lo'ta per l'affermazione dsılla loro libertá. Vivi applausi hanno rrimo i तो a di.m si. mentre sul palchetto andavano susseguendo alcune poesie italiane e slove. ne. Fra le poesie, recitate tuttie con entrisiasmo, la piu efficace e stata quella dalla piotiera $\mathrm{Ca}$ mina Ju. vich che ha dato ai bellissimi versi, compilati dal prof. Domenico venturini in onore alla nuova scuola, il calore e il sent'mento che essi richiedevano. Ben riuscita pure la can-

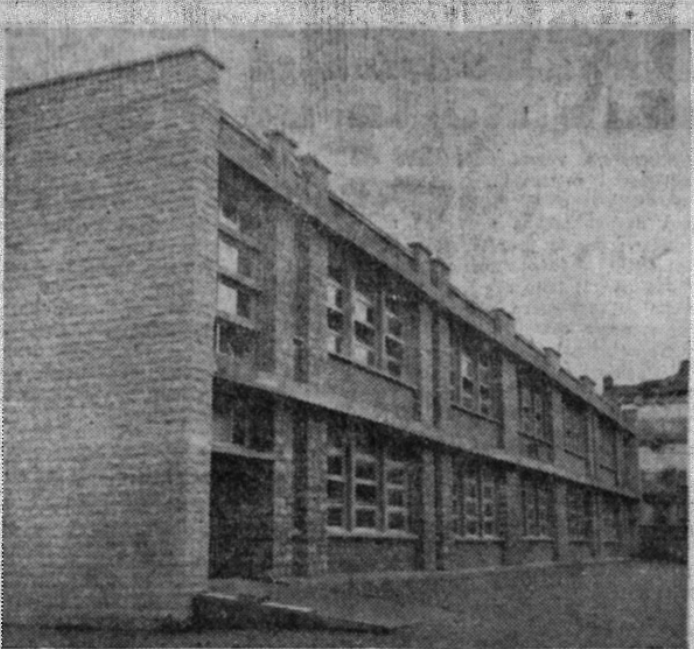

II primo pardiglione della nuova scuola servando i pavimenti luciai, 10 spo- sano principio di essere e rimanere gliatoio eisteticico e igienico aiviso dal l'aucia, la sorivania per l'insegnante. Su t t to cre a da commentare, iutto doPerisino l'amria parete in vetri, che illumina ogni aula e che permettera ai raggi del sole di pasarsi su quelle testoline intente allo stid o che fio of

intere non lo vegevano. Le aule sono in numero di sedici e sono riservate urldici jer gli scola i italia. i e ci. per quelli sloveni. In altesa che anche il secc do badigione verga costruito, si contivueranno i turni come si faceva finora e, g orna'mente, i ragazfratelli.

Con l'inaugrurazicne della nuova scuola, anche alcuni insegnanti, ancora troigpo attaccati ali aurtuc in icie vranno inaugurare uno tutto nuovo che avvii la nuova generazione nella concsicenza del progresso socialista. Ed essi dowranino essere 'I primi a rendere sempre piu saldo il fraterno legame tra gli italiani e sloveni insegnardo ai bimbi, affidati alia to.0 ed cazione, che, come sia italiani che sioveni lottarono uniti per la nostra liverazione e mo-ifuno imenslando la loro vita per veri d!ritti, cosi a:i-

Figure 1: Ervinio Velušček, New Italian-Slovene elementary school (later elementary school of Janko Premrl Vojko) in Koper, 1948-1951 (source: La nostra lotta (a), 1951).

The building was demolished in 2008 . 
Meanwhile, a longer lasting process of population transfer was already taking place in FTT's Zone B, parallel to those in other contested areas of Europe, such as Czechoslovakia, Poland and Ukraine (Ther, 2001, 52-58). In fact, since 1945, the local and mainly Italian-speaking urban population had already started emigrating to Italy; at the same time, newcomers from inner Slovenia and other Yugoslav republics began immigrating to the region (Kalc, 2019; Gombač, 2006). The FTT was dissolved in 1954 with the London Agreement that defined the borderline, which annexed Zone A to Italy and Zone B to Yugoslavia. It was a breaking moment since the new border split the organically developed region into two different states with different political systems. Following this political and demographic shift, a major economic development began in the newly acquired Yugoslav region - the final switch of powers took place. The new era of the city also required a new spatial development. A comprehensive regional plan, designed in 1959-1963 by the architect Edo Mihevc, became a dispositive of implementing the new socialist ideology, based on modernisation. It included also several demolitions of historic tissue that technically were aimed at improving the physical living standards of the population. The multi-ethnic character of the region was supposedly considered by designing the new architecture with reference to traditional vernacular features. However, the approach was also aimed at establishing a visual continuity in line with the environment, but not the social context, thus hindering and in fact supporting population change. Symbolically, these were acts of marking the space by erasing material references to past memories, and instead creating references for a new memory and identity or, as Piero Purini (2010) termed it, the Istrian area was undergoing a long-term ethnic metamorphosis. In this, the ideal of fratellanza of the interim period of FTT was replaced by the new ideal of Yugoslav socialist patriotism.

\section{Oreste Dequel, a subversive artist}

Two sculptors played a key role in post-war Istria: Oreste Dequel, in the period of the FTT, and Jože Pohlen from the 1960s onwards. The two artists are exponents of the hybrid identity of the Istrian population and embody the two main identifications Italian and Slovenian. On the other hand, their works illustrate two different moments in the Istrian post-war period. While Pohlen's thoroughly researched oeuvre mostly focuses on the rural hinterland, Oreste Dequel, whose few works survive in the cities, remains almost unknown to the Slovene public. One of Dequel's works has marked the public space of Koper since its creation: the bust of Pier Paolo Vergerio il Giovane, which we shall look at in more detail. 
Oreste Dequel is an enigmatic figure: known on the international artistic scene, he is almost completely unknown and missing from Slovenian overviews of $20^{\text {th }}$ century sculpture. Oreste Dequel (17. 8. 1923-24. 3. 1985) was born in Koper, originally came from the nearby village of Šmarje (Perfetti, 1991, 13; Tomizza, 1984, 59), and already in his teenage years had started drawing and participating in local competitions. During World War II, he took part in the national liberation struggle as an official of the Brigata Garibaldi, establishing links with Soviet and Yugoslavian freedom fighters. After the war, he received a national grant from the Yugoslav state to study at the new Slovenian Art Academy in Ljubljana, where he attended between 1946/47 and 1951 the seminar of the highly respected sculptor Professor Frančišek Smerdu, and was the classmate of Jože Pohlen (ALU 1995, s. p.). After his studies, he returned to his hometown Capodistria ${ }^{5}$ in 1951 and migrated to Italy in 1956. In his Trieste period, he produced a series of Bathers and Women Swimmers, the latter were presented at the Biennale in Venice. In 1959, he moved to Rome and established close links with Giorgio De Chirico, Filippo De Pisis and Renato Guttuso. In 1964, Dequel participated in the Italian exhibition in the World House in New York. From the 1960s, he produced several works for different southern Italian cities. He also worked in Australia, while in 1980 he was also a lecturer at Iowa University (Perfetti, 1991; Vidmar, 2005, 177).

For our purposes, Dequel's work immediately after the Academy is of interest. Soon after the conclusion of his studies in Ljubljana Dequel returned to his native Capodistria for a short period, during the period of the FTT. Together with Pohlen he shared an atelier and a small flat in a palace in the historic centre. He is remembered by contemporaries to have brought into "the urban environment the student atmosphere" as well as political provocations ${ }^{6}$ (Tomizza, 1984, 59-60; see also: Oreste Dequel (1923-1985), Spominska razstava, Delo, 21. 3. 1997, 11). In this short period, during the early 1950s, Dequel is recorded (Vidmar, 2003) as having produced in Koper a number of bronze busts of prominent historic cultural personalities, although today these are lost. The bronze busts included those of the most significant Slovenian writer, Ivan Cankar, the main Slovenian national poet France Prešeren, and the Italian composer Giuseppe Verdi - all three were made for the theatre foyer of Koper. Furthermore, Dequel is said to have made

5 We use here only the Italian name of the city since Dequel, as Italian-speaking local inhabitant, referred to it with this name.

6 His presence in the town in the early 1950s is documented in the novel Il male viene del nord by his compatriot and friend, the writer Fulvio Tomizza; the writer refers to the jolly nature of the sculptor who often acted out in controversial burlesque, somehow cynical, transgressing the acceptable norms of the new post-war regime. On occasion of the carnevale, the sculptor and a friend supposedly dressed in costumes; the friend as a donkey and Dequel with a moustache and gesticulations resembling those of Hitler (Tomizza, 1984, 59-60). The story told in this unique, very personal reportage about the artist is indicative of his attitude towards the authorities. 
other busts of Cankar and Prešeren, and a bust of Dante for the municipal library, as well as more busts on commission of local intellectuals, among which were professors of the Italian secondary school. One of the commissioners, Professor Babuder, is supposed to have been portrayed as well, with the bust to be located inside the Italian lyceum. Most of these artworks seem to have been lost, and only two publicly accessible pieces are signed and clearly attributed to Dequel today in Slovenia: the bronze bust of Pier Paolo Vergerio Il Giovane (1951) in Koper, and the sculpture of the Fallen Sailors (1953), later renamed Solidarnost/Solidarietà (Solidarity), in Izola.

\section{Bust of Pier Paolo Vergerio il Giovane in Koper: fratellanza}

In October 1951, the local Istria newspaper in Italian, La nostra lotta, called for a prize of 150.000 dinari for the realization of a bust of Pier Paolo Vergerio il Giovane (La nostra lotta (d), 1951, 3). The call was prepared under the aegis of the multicultural Society of Historians of the Yugoslav Zone of the FTT (SI PAK $\mathrm{KP} / 260$, a.e.1, 484/5). Vergerio was a $16^{\text {th }}$ century bishop of Koper who converted to Protestantism, and thus a prominent figure in the Reformation movement in the region. Until the post-war period, this personality was completely ignored and unknown, and only attracted interest as late as after World War II in the context of the socialist revolution and under the Slovene authorities (Tomizza, 1984, 59). The call and related articles in the newspaper clearly indicated the ideological context that brought to light this figure. Vergerio was identified as the historic "symbol of brotherhood between our nations" (La nostra lotta (a), 1951, 2). Vergerio's engagement with Protestantism led him to forge tight links with the key Slovenian Protestant Primož Trubar, author of the first book in the Slovene language and a fundamental figure within the Slovenian historic struggle for emancipation ( $\mathrm{La}$ nostra lotta (c), 1951, 3; La nostra lotta (b), 1951, 3). The Reformation and spread of Protestantism was a key and symbolic period during the Slovenian national struggle for emancipation, anticipating Slovenian national autonomy. On the other hand, the Protestant bishop was also perceived as a representative opponent of the mainstream feudal establishment. The choice of the subject, in 1951, therefore had several meanings, the main ones being the ideal of fratellanza, along with revolution and Slovene national emancipation. However, as the writer Tomizza observed (1984, 58), the promotion of Vergerio's historical role can also be read as a dispositive of post-war Slovene political authorities to prove the centuries-long presence of the Slavic/Slovene population in the urban areas of Istria. 


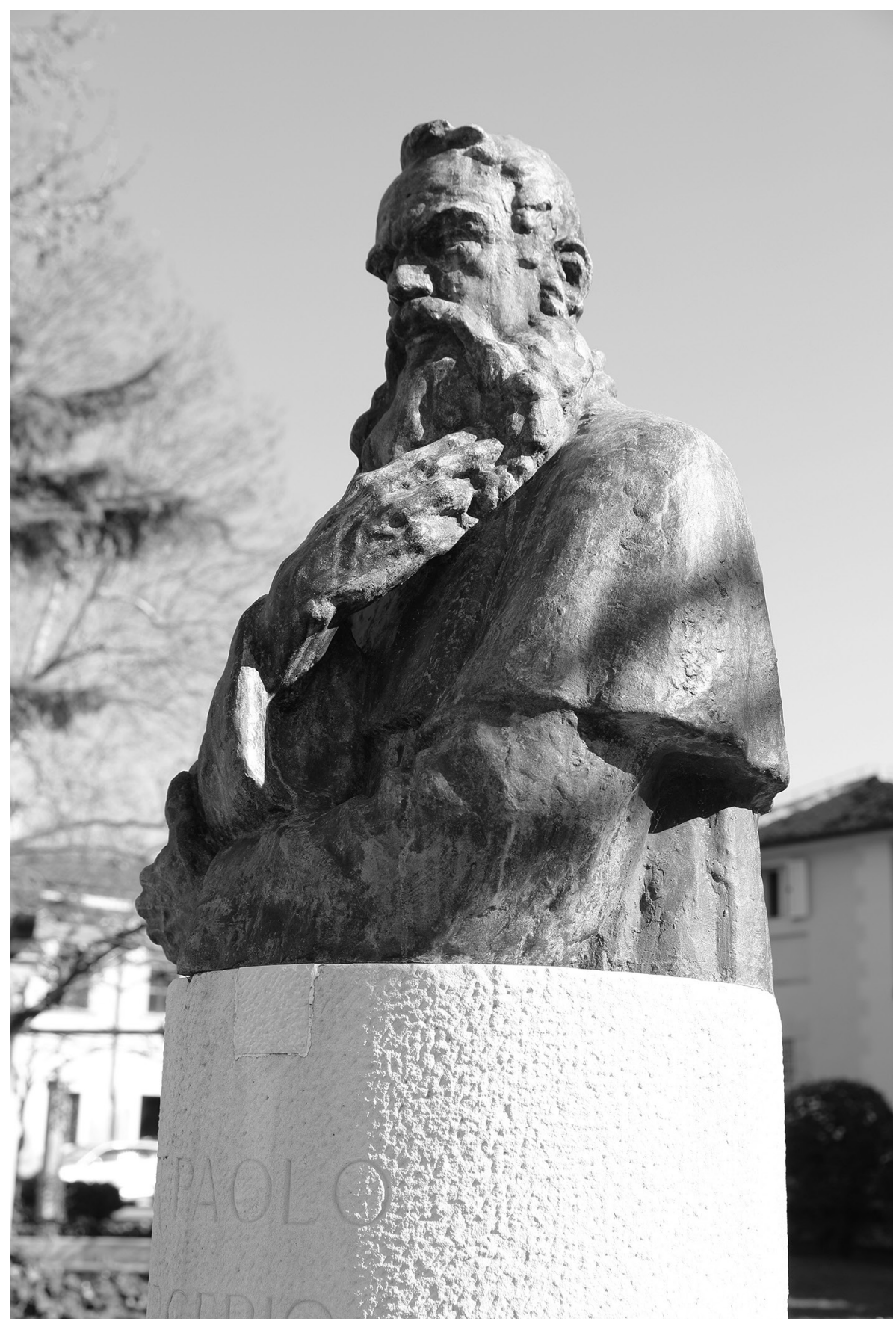

Figure 2: Oreste Dequel, bust of Pier Paolo Vergerio il Giovane on Vergerio square in Koper, 1951 (photo: Neža Čebron Lipovec 2019). 


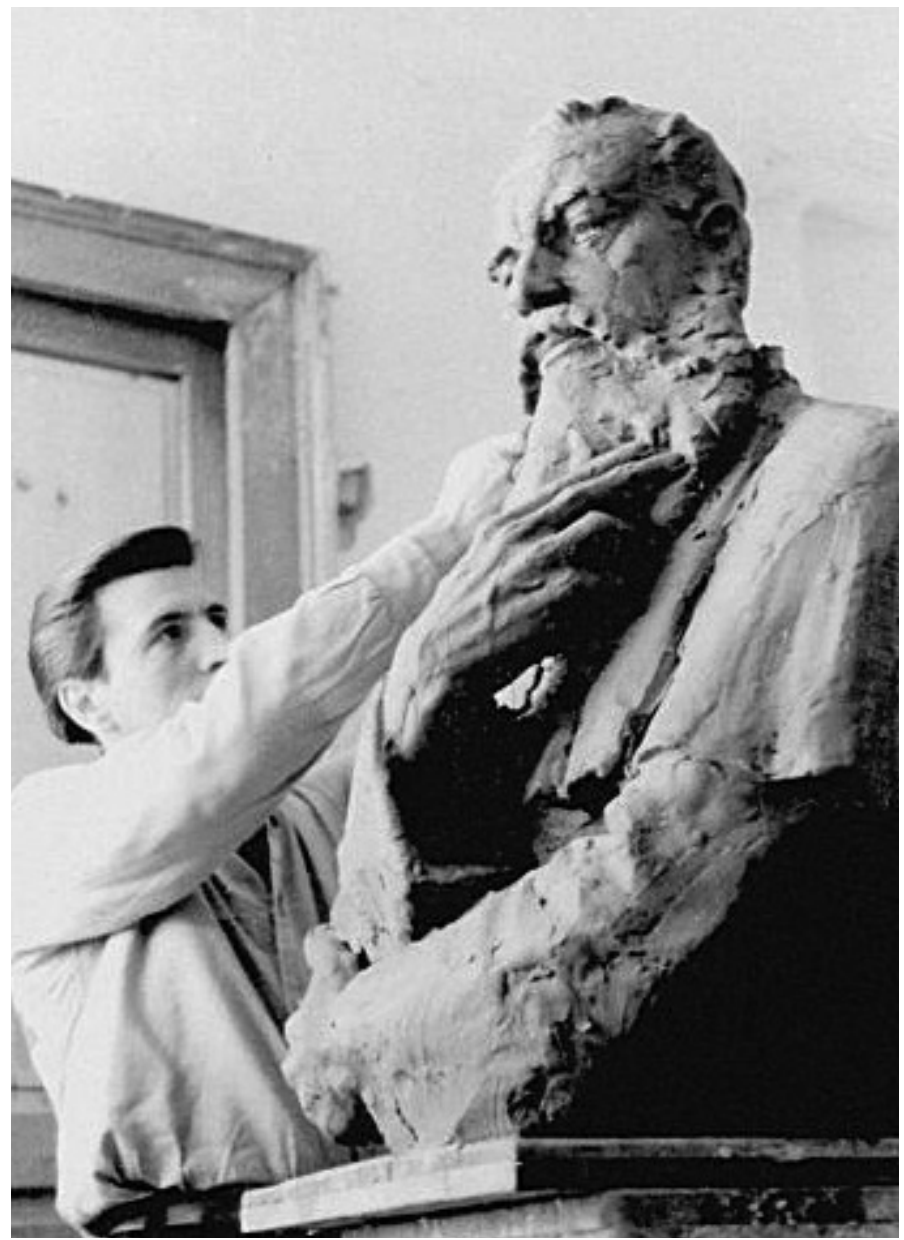

Figure 3: Photograph of the artist Oreste Dequel while working on the bust of Pier Paolo Vergerio il Giovane

(source: Vidmar, 2005, original in Archive of the Regional Museum of Koper).

Dequel entered and won the call. However, his monument to the great Protestant figure did not adhere to the canons of Socialist Realism, still in vogue in Yugoslav public art in the early 1950s (Čopič, 2000). The post-war period in communist countries was defined by Socialist Realist art as a normative doctrine aimed at presenting the optimal projection as vision of a socialist society that was not an unachievable utopia, but possessed "the possibility of choosing between different possibilities in time" (Šuvaković, 2015, 35). Art was used as a didactic tool for mythologizing the key political ideas and personalities using realistic presentation, in easily understandable forms and with a narrative content. After the Cominform break, Yugoslav art was 
reoriented towards Socialist Modernism, and opened up to Abstract Expression; but during the activities of Dequel in early 1950s in Koper, the influence of Socialist Realism was still strong.

Dequel's bust features naturalistic elements, yet it does not aim for monumentality, but rather to introverted, contemplative reflection. It can be described as innovative, in terms of form and meaning, because of the integration of both arms in the sculpture. The left hand supports the right hand, which grasps at the thick beard, marking the moment of introspection and thought. In his novel on Vergerio, Fulvio Tomizza provides the most eloquent description of the sculpture:

The figure of the bishop was coming out tall and vigorous, with severe features. The short and curly hair joined with the thick beard that rested on the chest on part of a robe. A beautiful wide forehead, round, attested to the intelligence and aptitude for study, it also indicated a discreet stubbornness, accentuated by the long and arched eyebrows, under which dilated eyes, a little protruding but almost watery, seemed to contemplate the trap of the world and, together, the fragility of human feelings. The image the figure gave was not of a positive character, that of the hero, but rather that of a formidable antagonist, dedicated and resolute, conscious of his own value. (Tomizza, 1984, 60)

Dequel managed to surpass and challenge the ideological constraints of the day. What was intended to be the political mythologization of a topic from the past was in fact subverted by the artist. The subject of such a cultural personality epitomizes Slovenian inter- and post-war production (Čopič, 2000, 90-96), since culture, especially literature, was the bearer of the Slovenian language, thus representing a basic tool for propagating Slovenian national memory. However, the sculpture reveals a very individual approach and interpretation of a figure that had to acquire an identity-building role for the region. Instead of a monumental memorial, intended to glorify the future-building power of the (revolutionary) intellectual Dequel produced a monument to a universal intellectual who questions all authorities. He stressed these aspects of Vergerio with the critical, dubitative and introspective look on his face, and the scepticism with the right hand holding the chin. In this subtle, yet subversive act, we may sense not only the artist's scepticism towards the new regime but even towards the concept of fratellanza. Despite this approach, incongruent with the spirit of the post-war revolutionary period, the artwork was accepted and placed in the public space. After a dispute on the location of the sculpture (Tomizza, 1984, 61), it was placed in the square-to-be in front of his house, where it still stands today, called Vergerio's Square.

7 All passages from Tomizza's novel were translated for the this paper by the author of the article. 
The sculpture of Vergerio is illustrative of the turbulent course of events that marked post-war Istria. In choosing a static, introverted portrait of the humanist, it is also a refined criticism of the contemporary mass production of baroque-looking memorials glorifying revolution (Čopič, 2000, 188-190). At the same time, it is also a tribute to the artist's hometown. In fact, again, Tomizza read in the features of Vergerio a network of associations and resemblances with the past inhabitants of the old city:

he [the figure of the bishop] appeared purely "Capodistrian" [typical of the town Koper/Capodistria] in his facial features that lived on in the memory of his people: the eyes recalled in me immediately a pal of my brother, the so-called Carlon, while the lips, even too finely modelled, almost feminine, reminded me both of a girl from the penultimate year of high-school as well as of a guy that played centre in Medusa [the local football club]. In his personal interpretation of the personality, erroneous as much as mine had been, the sculptor Oreste had focused on the bony hands, which for me were those skinny yet audacious hands of the old Babuder (Tomizza, 1984, 60-61).

Vergerio's bust can be defined as a double sign in the space. For the remaining Italians, it represented a reference to the local collective memory by accounting for their local history, through these subtle nuances, recognizable only to those who knew local personalities such as Professor Babuder. ${ }^{8}$ Conversely, for the Slovenian newcomers, the personality of the Protestant bishop referred to their national memory. By connecting the figure of Vergerio with the two ethnicities of the region, the artist connected the two historic periods of the city of Koper and Istria as a whole. As Tomizza observed, Dequel's Vergerio marks the last point of encounter as well as the historic break up, when the old city - along with its collective memory - started to disappear with the mass emigration of its previous inhabitants, and a new city that grew on its place: "An artwork of the new city Capodistria, which in its way, made her first and last homage to the old city that remained empty" (Tomizza, 1984, 62). Despite his connections with the Slovene Communist authorities and his role in World War II, Dequel left Koper in 1956 and moved to Trieste, as was the case with the majority of Italian-speaking Istrians.

\section{Conclusion}

Research into the complex post-war context of northern Istria showed that the quest for collective memory is particularly sensitive in contested multi-ethnic spaces. Architecture and art, namely public sculpture, as vehicles of representation of power,

8 Most likely, it was in that same period that the artist also produced the bust of professor Francesco Babuder (Vidmar, 2005, 177), a renowned docent of the Capodistrian Secondary School. 
play a determinant role in the dialectics of preserving/erasing memory, and thus heritagizing traces and signs of the past or, conversely, demolishing them.

Socio-political changes in post-war Istrian cities conveyed a demographic change that finally resulted in an ethnic transformation. Positions of power among the contending groups in the urban area switched: Slovenes became the majority, Italians the minority. However, the decade of the buffer-state FTT (1947-1954) marked a period of apparent overcoming of ethnic tensions thanks to the common cause of the National Liberation Fight and the brotherhood of the two ethnic groups. Just before Yugoslavia gained full authority over the multi-ethnic region in 1954, and started a process of wholesale spatial and social restructuring via Edo Mihevc's regional plan, the interim period of the FTT produced two unique structures: an elementary school for pupils of both ethnicities and a public monument. While the architecture assumed a representative and apologetic role, the sculpture attempted to take a more subversive stand, with the bust of the Istrian Protestant Bishop Pier Paolo Vergerio il Giovane in Koper, by Oreste Dequel. While the personality, chosen by the authorities, was selected as a symbol of post-war fratellanza, and thus was an expression of political ideals, the artist subverted the theme with the formal execution of the historic portrait, introducing scepticism and doubt as well as inserting references to the collective memory of the previous inhabitants of the city. The intervention was so subtle that authorities did not realize it, so the sculpture still stands today - although the meaning of fratellanza has been lost for decades.

\section{References}

\section{Archival sources}

Regional Archive of Koper:

SI PAK KP/260 Zgodovinsko društvo cone B STO, a.e.1, 484/5.

\section{Bibliographical sources}

Akademija za likovno umetnost ALU, 1945-1995, Ljubljana 1995.

Bonin, Z., Življenje v coni B Svobodnega tržaškega ozemlja, in: Cona B Svobodnega tržaškega ozemlja (1947-1954) (ed. Bonin, Z.), Koper 2004, pp. 9-59.

Čebron Lipovec, N., Arhitekturni pomniki izgradnje Kopra po drugi svetovni vojni, Annales, Series Historia et Sociologia 22 (1), 2012, pp. 211-232.

Čebron Lipovec, N., Izgradnja slovenskih obalnih mest $v$ času po drugi svetovni vojni: primer mesta Koper [doktorska disertacija], Koper 2018. 
Čopič, Š., Javni spomeniki v slovenskem kiparstvu prve polovice 20. stoletja, Ljubljana 2000.

Gombač, J., Oris reševanja nekaterih akutnih problemov pri obnovi gospodarstva v okraju Koper v desetletju po koncu druge svetovne vojne, Acta Histriae 14 (2), 2006, pp. 281-298.

Halbwachs, M., Kolektivni spomin, Ljubljana 2001 [1950].

Harvey, D. C., Heritage pasts and heritage presents: Temporality, meaning and the scope of heritage studies, International Journal of Heritage Studies 7 (4), 2001, pp. 319-338.

Kalc, A., The other side of the "Istrian exodus": immigration and social restoration of Slovenian coastal towns in the 1950s, Two homelands / Dve domovini 49, 2019, pp. 145-162.

La nostra lotta (a), Simbolo della fratellanza la nuova scuola elementare, La nostra lotta, 7. 3. 1951, p. 2.

La nostra lotta (b), Il $400^{\circ}$ anniversario del libro sloveno, Pier Paolo Vergerio il giovane è il simbolo della fratellanza tra i nostri popoli, La nostra lotta, 26. 9. 1951, p. 3.

La nostra lotta (c), Pierpaolo Vergerio (il giovane), La sua vita, la sua opera e la sua epoca, La nostra lotta, 10. 10. 1951, p. 3.

La nostra lotta (d), Concorso, La nostra lotta, 17. 10. 1951, p. 3.

Lefebvre, H., Produkcija prostora, Ljubljana 2013 [1974].

Low, S., Lawrence-Zuñiga, D., The Anthropology of Space and Place, Locating Culture, Hoboken (NJ) 2003.

Mileusnić, Z., Beneška dediščina na območju dominikanskega samostana v Kopru [doktorska disertacija], Koper 2015.

Oreste Dequel (1923-1985), Spominska razstava, Delo, 21. 3. 1997, p. 11.

Perfetti, R. (ed)., Oreste Dequel 1923-1985: mostra antologica, Trieste, Palazzo Costanzi, 17 October - 13 November 1991, Trieste 1991.

Purini, P., Metamorfosi etniche. I cambiamenti di popolazione a Trieste, Gorizia, Fiume e in Istria. 1914 -1975, Udine 2010.

Rogoznica, D., Iz kapitalizma v socializem: gospodarstvo cone B Svobodnega tržaškega ozemlja: 1947-1954, Koper 2011.

Rossi, A., The Architecture of the City, New York, London 1982.

Rotar, D., Pomeni prostora (ideologije v arhitekturi in urbanizmu), Ljubljana 1980.

Šuvaković, M., Art and Politics, in: Heroes we love. Ideology, Identity and Socialist Art in the New Europe (ed. Vidmar, S.), Maribor 2015, pp. 16-39. 
Ther, P. et al., Redrawing Nations: Ethnic Cleansing in East-Central Europe, 1944-1948, Lanham 2001.

Tomizza, F., Il male viene dal nord, il romanzo del vescovo Vergerio, Milano 1984.

Troha, N., Osimo in manjšine, in: Osimska meja (eds. Pirjevec J. et al.), Koper 2005, pp. 137-149.

Veschambre, V., Traces et mémoires urbaines. Enjeux sociaux de la patrimonialisation et de la destruction, Rennes 2008.

Vidmar, F., Umetnik mogočne izrazne moči, "po poklicu mačkar«, Primorske novice, 16. 8. 2003, p. 19.

Vidmar, F., Dequel Oreste, in: Istarska enciklopedija (eds. Bertoša, M., Matijašić, R.), Zagreb, 2005, p. 177.

Wingfield, N., The Politics of Memory: Constructing National Identity in the Czech Lands, 1945 to 1948, East European Politics and Societies 14/2, 2000, pp. 246-267. 


\section{Neža Čebron Lipovec}

\section{Poklon novega mesta staremu mestu: Dequelov doprsni kip škofa Vergerija mlajšega}

Ključne besede: kolektivni spomin, sporni kraji, simbolno označevanje, javna plastika, Koper, Oreste Dequel

Pojem kolektivnega spomina odpira temeljna vprašanja o vrednotenju dediščine, predvsem materialne stavbne dediščine $\mathrm{v}$ spornih krajih. Hkratna prisotnost različnih skupin $\mathrm{v}$ prostor uvaja vzporedne spomine in diskurze, ki jih lahko prepoznamo bodisi skozi odnos do stavbne dediščine bodisi v izvedbi javne plastike, oboje pa beremo kot simbolično označevanje prostora (Veschambre, 2008). Urbani prostor severne Istre, kjer sta se skozi zgodovino prepletali italijanska in slovenska skupnost, so političnozgodovinska dogajanja sredi 20. stoletja usodno zaznamovala. Povojno reševanje konfliktov je pripeljalo do vrhunca »etnične metamorfoze« regije (Purini, 2010), ko se je večinsko italijansko govoreče prebivalstvo izselilo iz mestnega prostora, vanj pa so se naselili Slovenci iz drugih slovenskih ter jugoslovanskih pokrajin. Nasprotja med Slovenci in Italijani v pokrajini so izvirala iz predvojnega, dve desetletji trajajočega fašističnega nasilja nad slovenskim prebivalstvom. Kljub temu je antifašistični boj združil oba naroda, predvsem v okviru komunistične ideologije. Tako je po vojni v Coni B Svobodnega tržaškega ozemlja (1947-1954) zaživel ideal fratellanze, bratstva med Slovenci in Italijani v Istri. Spomenik temu idealu je postavil - v slovenskem prostoru neznan - koprski kipar Oreste Dequel z doprsnim kipom koprskega protestantskega škofa Pier Paola Vergerija mlajšega, prijatelja Primoža Trubarja. Kljub takrat še prevladujoči socrealistični estetiki je kiparju uspelo s subverzivnimi potezami $\mathrm{v}$ eno podobo vplesti več kolektivnih spominov. 


\section{Homage of a New Town to an Old One: Dequel's Bust of Pier Paolo Vergerio il Giovane}

Keywords: collective memory, contested spaces, symbolic marking, public sculpture, Koper/Capodistria, Oreste Dequel

The concept of collective memory raises fundamental questions regarding the assessment of heritage, especially of built heritage in contested spaces. The simultaneous presence of different groups in conflict introduces into the space parallel memory discourses that can be recognised both in the built environment as well as in public sculpture, and both can be read as a symbolic marking of space (Veschambre, 2008). The urban space of northern Istria, where the Italian and Slovene communities have become intertwined throughout history, were drastically marked by the political and historic events of the mid- $20^{\text {th }}$ century. Post-war conflict-solving processes lead and an ongoing process of "ethnic metamorphosis" (Purini, 2010) in the region came to a peak when the majoritarian Italian-speaking population of the urban area emigrated, while the space was settled by newcomers from inner Slovenian regions and other Yugoslav republics. Tensions between Slovenes and Italians arose in the early $20^{\text {th }}$ century, especially from the period of Fascist oppression and violence against the Slovene population. Nevertheless, the antifascist struggle united the two ethnic groups, specifically within the Communist ideology, so after WWII the area of the socalled Zona B of the Free Territory of Trieste was marked by the ideal of fratellanza, the brotherhood between Italians and Slovenes in Istria. A monument to this ideal was created by a sculptor from Capodistria, Oreste Dequel, who is unknown in the Slovene context. The sculpture represented the Protestant Bishop of Capodistria, Pier Paolo Vergerio il Giovane, a friend of the key Slovene Protestant Primož Trubar. Despite the then leading Socialist Realist aesthetics, the artist managed to intertwine in the artwork, using a subversive approach, several collective memories. 